Una Vasiljević

Faculty of Philology

University of Belgrade
UDC $323.15(=163.41)(=135)(497.11)$

DOI https://doi.org/10.18485/fid.2017.7.ch15

\title{
THE CULTURAL IDENTITY OF THE ROMANIANS OF SERBIA AND ISSUES IN APPROACHING LANGUAGE AND TRADITIONAL BELIEFS IN SCHOOLS
}

\begin{abstract}
Рад настоји да илуструје културни идентитет Влаха/Румуна источне Србије, заједнице којој и сама припадам, и која је успевала да преживи на овим просторима упркос недостатку школа, цркви и медија на румунском језику. Власи су практично на раскрсници више култура, што чини ову билингвалну заједницу специфичном и вредном проучавања. Како би се приближили култури ове заједнице, дискутоваћемо о одликама попут митологије, језика и обичаја, праћеним малим речником натприродних бића која су популарна у овој области. Централни део рада је свакако образовање на румунском језику и његов значај.

Први део рада бави се пореклом и историјом тимочких Влаха/Румуна, уз кратку анализу четири дијалектских и етнографских група. Други и централни део посвећен је образовању на румунском језику, те ћу из угла професора навести примере из праксе. Завршни део рада бави се незаобилазним влашко-румунским митолошким универзумом у коме ће бити наведена три најпознатија демонска бића са ових простора.
\end{abstract}

Кључне речи: Власи, идентитет, образовање, заједница.

\section{Introduction}

Romanian peoples have long inhabited Serbian land bringing their customs, language and traditions to both Vojvodina, and Eastern Serbia and creating interesting bilingual multiethnic communities where Romanian and Serbian culture intertwine. Language is the most significant means through which tradition and identity are preserved, and what is most important, as long as it is active, so will the community be preserved. It seems that language has been the most important factor in the survival of the Romanians in Eastern Serbia for all those years, and for that strong ethnic instinct they possess. One might say that this is little short of a miracle, since this minority has succeeded in surviving in this area despite the fact that they have not always had schools, churches or administration in their 
language, unlike Romanians from Vojvodina, who have all that. Although children in Vojvodina have had education in their mother tongue for a long time, this was not the case in Eastern Serbia before 2013, which is very destructive because school is the place where national consciousness is continuously forming among children who belong to a minority population.

\section{Romanians or Vlachs?}

From the ethnical and cultural point of view, Eastern Serbia belonged to the Thracians, Romans and Romanians for a period of three thousands years. Romanians from Eastern Serbia call themselves Romanians, while the Slavic population uses the term Vlach. From the administrative point of view, this population belongs to the Republic of Serbia, while from the ethnic and spiritual side, the community is highly divided. Part of them identify themselves as Romanians, part are creating a new identity and language- Vlach, and part just say they are Serbs. In her work about ethnic stereotypes of the Vlachs in Serbia, Sikimic (2002: 187) quotes the opinion of French anthropologist, Dejan Dimitrijevic, who provided maybe the most acceptable explanation of the dual identity of the Vlachs, that the Romanian identity is expressed within the local Romanian/Vlach community, while they have a Serbian identity outside of it. If asked in Romanian about their identity, they will say that they are Romanians, but if asked the same question in Serbian, they will assert that they are Vlachs. Moreover, the language they speak and call Vlach speech is Romanian with certain dialectical particularities. Anthropologist Annemarie Sorescu-Marinkovic (2012: 49) defines Vlach speech as archaic Romanian with Slavic elements which has passed through a process of assimilation. Aside from numerous loanwords, this speech is characterized by a large number of neologisms taken from Serbian that adorn this speech in a specific way and contribute to the continuous enrichment of the vocabulary.

Language and costume, not to speak of other singularities, clearly show that the Romanian population from this area originate from various Romanian areas on the northern banks of the Danube, on the basis of which four dialectal and ethnographic groups were formed.Vâlsan (2003:109) claims that those are the Romanians from the mountainous 
western part who came from Hungary, so they are called Ungureni, while Romanians from the eastern part are called Țărani (rom.villager), and they came fromT,araRomânească. Ungureni are the largest group and they live in the areas delineated by the rivers Zapadna Morava, Crnareka, Danube and Timoc, and they speak a dialect that corresponds to the dialect from Banat. On the other hand, the speech of the Tărani, who inhabited the area of Kljuc and Negotinska Krajina, is very similar to the dialect from Muntenia, Romania. Other than these two groups there are two more:Ungureni - Munteni and Bufani; Ungureni-Munteni are a mix of Tărani and Ungureni, while Bufani inhabited the area of the mining town of Majdanpek. There are Băieși also, whose mother tongue is Romanian and who live in the remote villages of Timoc.

\section{Education in Romanian Language in Eastern Serbia}

In his travel writings at the beginning of the $20^{\text {th }}$ century, Tihomir Djordjevic (1906: 23) describes that while traveling through Eastern Serbia he visited one elementary school where he had an opportunity to hear Romanian pupils sing in their mother tongue. This is practically impossible nowadays because children of Romanian nationality do not speak in their mother tongue. They grow up in a bilingual environment where they speak their mother tongue - Romanian at home, but Serbian in school. These children have never had any Romanian lessons, so their language skills are often weak, and they are not familiar with history and culture of their wider ethnic group. They are familiar only with the Romanian that is orally transmitted in the family and that they call Vlach language because that is the speech of their ancestors. As schools in their mother tongue do not exist, in order to acquire an education, the children have to learn Serbian, the language of the majority population, before going to school, and practically leave aside forever their identitary roots. Aware of the situation they are in, members of the Romanian national minority in Eastern Serbia have strived for years to provide the conditions for Romanian language preservation in this area for their successors and advocated with the Serbian authorities for opening the Romanian schools. The first significant step was made in 2013 when the subject 'Romanian language with elements 
of national culture' was introduced for the first time in elementary and high schools through a pilot project approved by the Ministry of Education of the Republic of Serbia, and conducted by the National Council of the Romanian Minority from Novi Sad. As the name suggests, the subject deals with Romanian language as such, with an introduction to Romanian culture and literature, and the lifestyle of the Romanian people. In 2013 it had the status of an optional subject which changed a year later when it became an optional obligatory subject, which means that if the pupil decides to learn Romanian, those lessons are obligatory and regular attendance is mandatory. Groups are formed on the basis of questionnaires which are sent to schools by the Ministry of Education, and filled in by the pupils and their parents. According to the data of the School administration of the city of Zajecar, in 2013, when the pilot project was carried out, 1617 pupils from the municipalities of Boljevac, Bor, Zajecar, Kladovo, Majdanpek and Negotin chose to learn Romanian language with the elements of national culture, of which 655 are the pupils from elementary schools and 962 pupils from high schools. Since the pilot project proved to be very successful, children continued to learn Romanian in the following years.

Being a member of the Romanian national minority myself, it is a great privilege to me to be a professor of Romanian language and contribute to the Romanian identity and culture preservation in this area through daily work with children. For the purpose of independent research (see Annex), which was the part of my masters dissertation on the subject Teaching Methods of Romanian Language with Elements of National Culture in Eastern Serbia, pupils who attend my classes took part in an anonymous questionnaire that was carried out in May 2015. As among them are also the children of Serbian nationality, I was wondering what made them learn this language they are unfamiliar with. I also wanted to know how children of Romanian nationality adopt it since, as we mentioned before, they know just the oral variant in the form of Vlach speech, and whether this facilitates learning Romanian or makes it more difficult.

As to motivation, $12 \%$ of them attended classes because their parents made them. According to this, we can conclude that they show an interest in mother tongue preservation, so they are not totally assimilated. Other pupils attend classes because they love Romanian language and culture because they have already been learning it (75\%) or visited Romania; 31\%, mostly 
high school students who want to study in Romania, while others learn it because of friends or because they are keen on languages in general. The results have shown that as many as $83 \%$ of pupils come from bilingual families where Vlach and Serbian are spoken, and $75 \%$ of them are familiar with Vlach speech, which means that those $8 \%$ for some reason do not speak their mother tongue. Judjing by personal experience I suspect one of the reasons may be the fact that they had to learn Serbian language since they attend Serbian schools, so their mother tongue was not spoken in their environment.

On the other hand, these same children who speak Vlach declared that knowing Vlach speech helped them in Romanian language acquisition. For them, this is both a mitigating and aggravating circumstance; mitigating because they are already familiar with vocabulary because of the similarity between Romanian and Vlach so they learn words faster, but aggravating because the questionnaire results showed that $39 \%$ of them have difficulties as far as writing and reading are concerned since they did not speak the Romanian literary language, but rather Vlach speech, and they have not seen Romanian books at all. The Romanian ethnic community from Vojvodina used to have the same problem of illiteracy and lack of standardized language in the thirties of the last century, but they soon were able to open schools in their mother tongue. The situation improved after 1945, when the Cultural Association of Romanians from Yugoslav Banat was formed in Alibunar, and they were allowed to open printinghouses in which they issued texts in the Romanian standard language. (http://www.banaterra.eu/srpski/ZZ/ziveti\%20zajedno/).

Observations from classes suggest that these children really have difficulties in reading and writing and tend to write and read as they hear Vlach speech. As Djordjevic (1906: 13) notices, the speech of the Ungureni differs from Romanian literary language in some consonant pronunciations $-\mathrm{c}, \mathrm{d}, \mathrm{l}, \mathrm{n}, \mathrm{t}$. In Romanian literary language we would say rece (cold), unde (where), limba (language) but the Ungureni from Timoc would say reće, unđe, ljimba.

\section{The Mythological Universe}

Perhaps the most significant feature of the entire Romanian-Vlach identity is the mythological universe that is ubiquitous in modern society 
and by which Romanian/Vlachs are known. Timocka Krajina represents a place where elements that belong to traditional Romanian culture have revived elements that have disappeared within the Romanian borders. Mythology and demonology are not taboo among Romanians from Timoc, on the contrary, they are very available. As for their beliefs, despite the fact that their tradition is related to birth, weddings and funerals, and is similar to beliefs among Romanians from Hungary, their system of beliefs is a fascinating mixture of Christianity and Paganism. These beliefs include the existence of werewolves and the return of dead people forty days after their death, the marking of old people with a hot iron to prevent them being caught by death, and many others. On the other hand, this community adopted the institution of the 'slava' from the Serbs, the celebration of a Christian saint's day, who is considered to be the family protector. The mythological universe of this community is formed by the overlapping of folklore motifs from Romanian and Slavic mythology. There is no Vlach mythology as such, it is made up of plenty of mythological texts that were collected by various authors who wrote from their personal experience. Sorescu - Marinkovic (2012:92) notes that there are three demon beings, which appear in the repertoire of almost every interlocutor of Timocka Krajina (both in Romania, Serbia, and in the entire Banat region). They are related to three important periods in one's life: birth (Ursitoarele- the Faiths), adulthood (Zburătorul - an evil demon which attacks young women, maybe a relative of the well-known Dracula), and death (Moroiul - the Ghost). Those mythological demons are considered to be active because Romanians from Eastern Serbia talk about them in the present tense, from 'personal experience' and undertake 'actions' which neutralize them.

All those who wrote about the beings present in Vlach folklore have inevitably mentioned Ursitoarele (the Faiths), those three girls who are also popular in Serbian mythology. Durlić (1995: 239) notes that Vlachs/ Romanians use terms which ethnology associates with Latin heritage, as much as Slavic, including ursa, fata, sudina. It is believed that there is no force that can change destiny after they predict it. They are three sisters, young and beautiful, dressed in white with unbounded hair and they appear in the first three nights after the child is born. According to a belief in Timoc, mother and child should sleep on the floor, the house should be cleaned, and a table set up for them (the table is prepared by the midwife). There are three cakes coated with honey on the table, three glasses of wine, 
three glasses of water, three pieces of sugar and one ducat. After the Faiths arrive, three men should eat the bread, if the child is a boy or three women if the child is a girl, and the ducat remains for the child. It is also believed that the Faiths enter the house stealthily and if they do not find anything on the table, they predict a tragic fate for the newborn.

Although in Serbian mythology Zburătorul is a demon being with a series of different functions, among Vlachs/Romanians from Eastern Serbia this being (as they call it - zmău) occurs exclusively in an erotic connotation. It is a dimorphic being, half human, half animal, which is imagined as a long tailed bird which transforms into a human before contact with them. (Sorescu - Marinković, 2012: 195). It lives in mountains or woods near the rivers and its most expressive characteristic is erotic potential. Because of the belief in the incredible potency he possesses, women are pale and exhausted after contact with him, and they lose desire for other men. Women who want to escape from him should find a lacuna where they live and burn it. Another significant function of this being is the fight against the dragons that bring storm clouds.

It is noted in most reports about the beliefs in Timocka Krajina that the cult of the dead is very complex, as is the whole ritual of the funeral and everything that follows it. There is also a belief in Moroi - the Ghost. The first who wrote about it was the doctor Stevan Macaj, in the 70s of the $20^{\text {th }}$ century, who researched how a dead body transforms into a vampire. (Sorescu - Marinković, 2012: 112). In order to prevent it, a spindle should be put next to the dead man's head. Moroi can be born of people who died on Tuesday, Thursday or Saturday. It is also believed that people who are struggling on their deathbed should be branded with hot iron on the neck because this protects them from transformation into a vampire. Recent researches about vampires have shown that live vampires are called Pricolici and that they torture newborns in cribs, while those real vampires are called Moroi. This belief is similar to the Serbian one, but in contrast o this, this one is more widespread and more developed. (Durlić, 1995: 239)

\section{Conclusion}

The memory lives and is maintained through communication. If this is interrupted it disappears, or if the framework of relations in the com- 
munications reality is changed, the consequence is oblivion. People can recall only that which is communicated and what they can localize in the collective memory. Schools as institutions are the place where the cultural identity of a community has to be maintained, through collective activities with the same aim, so introducing Romanian language with elements of national culture is very important for the Romanians from Eastern Serbia. Culture and tradition are the bases of every nation and community, so it is unacceptable in today's society that an individual should not be able to use appropriate terms connected to today's lifestyle. As the name of the subject suggests, its purpose is introduction to the concepts of modern life within the community and beyond that can be used in everyday communication (for example - when buying a bus ticket, a person should be familiar with the word bilet, rom. ticket). Subjects that are approached are connected with the environment, everyday life and communication, terms from the Romanian lifestyle are present, too (costume, customs that are practiced, popular songs and culture in general), while on the other side children enrich their vocabulary and culture of expression through literary texts and poetry. I need to mention that the promotion of minority languages in Eastern Serbia is more than necessary.

Like the Romanian minority from Vojvodina, the Romanians from Eastern Serbia should also have the right to schooling in their mother tongue, because the schools are the place where ethnical identity can be preserved, while remaining faithful citizens of their motherland, which is Serbia.

\section{References:}

Durlić, P. (1995). Cult of the dead as the basis for determining the religion of the Vlachs, in: Ethno - cultural code. Svrljig. (In Serbian)

Đorđević, T. (1906).Through our Romanians.Belgrade: SvetozarNikolić printing house. (In Serbian)

Sikimić, B. (2002). Ethnic Stereotypes About Vlachs in Serbia, Cultural and Ethnic Identity in the Process of Globalization and Regionalization of the Balkans. Niš: Junir. (In Serbian)

Sorescu - Marinković, A. (2012). Romanians from Timoc: Mythological Beings. Cluj - Napoca: Agronaut. (In Romanian) 
Vâlsan, G. (2003). Romanians from Bulgaria and Serbia. Zaječar: Ariadne filum. (In Romanian)

Vasiljević, U. (2015). Teaching Methods of Romanian Language with the Elements of National Culture in Eastern Serbia. Unpublished master thesis, University of Belgrade. (In Serbian)

Living Together, Minority Communities in Vojvodina: Romanians. (2015, June 26). Retrieved fromhttp://www.banaterra.eu/srpski/ZZ/ ziveti\%20zajedno/(In Serbian)

\begin{abstract}
This work aims to illustrate the cultural identity of the Vlachs of North Eastern Serbia, a community to which I myself belong, and which has succeeded in surviving in this area despite the lack of schools, churches and administration in their native language. The Vlachs are practically at the intersection of several cultures, which makes this bilingual community specific and worth researching. In order to approach the culture of this Romanian community, features such as folklore, mythology, language and customs, followed by a short dictionary of supernatural beings will be discussed. The central part of the work is surely education in Romanian language and its importance.

The first chapter provides landmarks for the origins and history of the Vlachs/Romanians with a brief analysis of the four dialectal and ethnographic groups. The second, and the central part deals with education in Romanian language. Therefore, from the perspective of a professor, I will give examples from practice. The final part is dedicated to the unavoidable mythological universe of the Vlachs/Romanians, in which three demon beings will be described.
\end{abstract}

Keywords: Vlachs, identity, education, community

\begin{abstract}
Annex
As a research instrument for my masters dissertation, an anonymous survey on Romanian classes was made in May 2015 in the schools of the municipalities of Zajecar and Boljevac where children study Romanian language. The respondents are pupils aged 7-18. The purpose of the questionnaire is to examine the motives for language learning, understanding of Vlach speech, and difficulties in Romanian language acquisition.
\end{abstract}


The questionnaire included 77 respondents who answered 6 questions.

\section{I chose to learn Romanian}
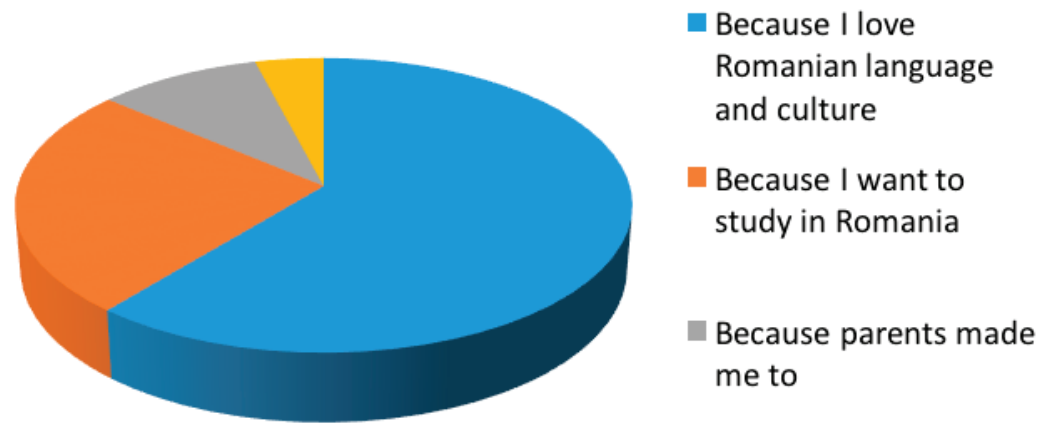

- Because I love Romanian language and culture

Because I want to study in Romania

Because parents made me to

Other

When asked about the motives for learning the Romanian language, respondents were able to circle more than one answer:

$75 \%$ of them said that they love Romanian language and culture because they visited Romania or they have already learnt it.

$31 \%$ said they want to study in Romania. These are high school students.

$12 \%$ said that they decided to learn Romanian because their parents made them since they originate from bilingual families.

$5 \%$ gave other reasons:

- They want to know as many languages as possible

- A friend talked about Romanian

- It is interesting to learn something new

- So they could talk with parents 


\section{I was familiar with Vlach speech before}

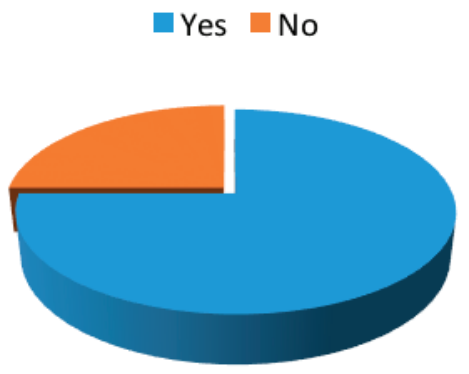

When asked if they were familiar with Vlach speech before Romanian classes, $75 \%$ answered affirmatively and $25 \%$ negative.

\section{The knowledge of Vlach speech helped me in Romanian language acquisition}

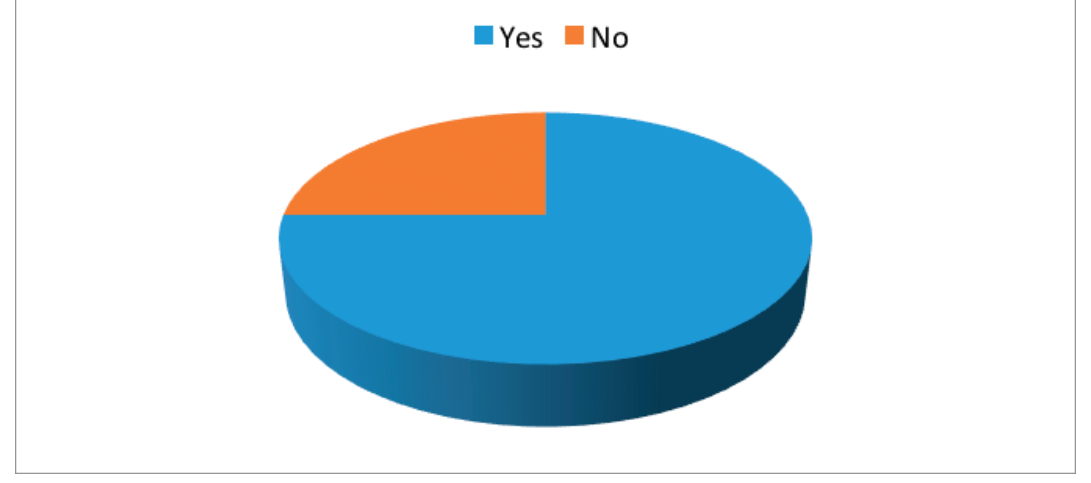

Respondents who are familiar with Vlach speech acquire Romanian language more easily. 


\section{Vlach speech is spoken in my family}

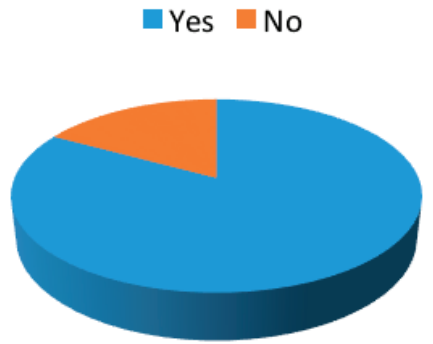

$83 \%$ of respondents come from families where Vlach is spoken, while $17 \%$ do not.

\section{The major difficulty in Romanian language learning is}

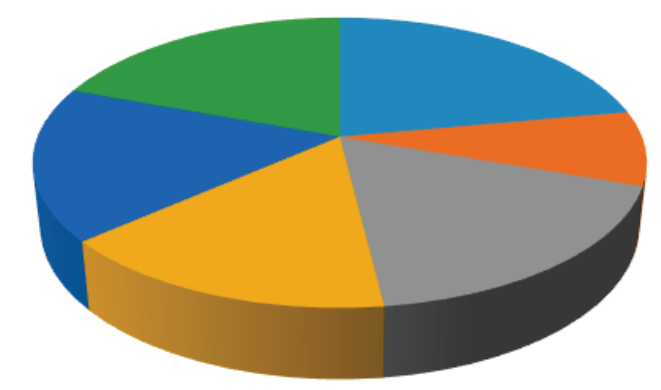

Vocabulary

- Spoken language understanding

Reading comprehension

Grammar

On questions 5 and 6 respondents had the option of choosing more than one answer:

$40 \%$ said that vocabulary is a problem; 35\% have difficulties in speaking; $32 \%$ do not understand written text; $31 \%$ have the problem with 
writing; $28 \%$ have difficulties in grammar learning; $15 \%$ do not understand spoken language; $5 \%$ do not have difficulties in Romanian language learning.

\section{In my opinion, the most interesting aspect in Romanian language learning is}

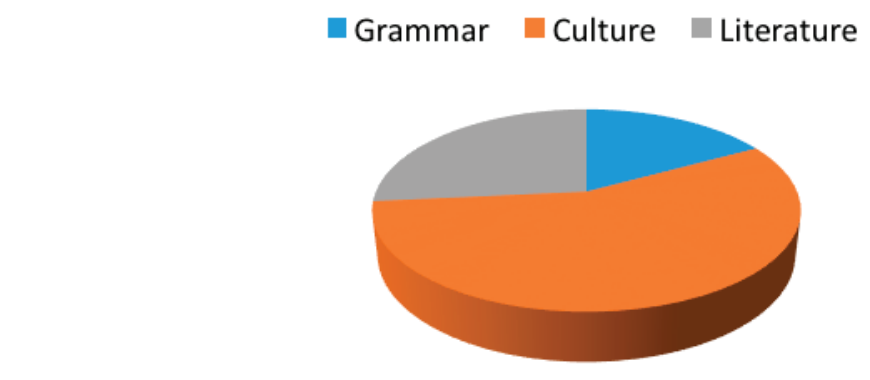

As far as the most interesting aspect in Romanian language learning is concerned, students consider the Romanian culture the most attractive $(83 \%)$, followed by literature $(39 \%)$, but the less engaging is the grammar $(25 \%)$.

As we can conclude, the students who come from families where Vlach is spoken adopt Romanian much more easily, but at the same time have difficulties in reading and writing because they did not have an opportunity to learn the Romanian literary language. Also, it should be noted that $12 \%$ of students who come from such families attend classes because parents made them, which means that they support preservation of cultural identity where the language plays the most important role. 


\section{Biographical statement}

UNA VASILJEVIĆ is a professor of Romanian language and literature in primary and high schools in Zajecar, Serbia. After completing academic studies at the Faculty of Philology, University of Belgrade, department of Romanian language and literature, she received her master's degree in Romania, Faculty of Letters, University of Craiova - English language, Theoretical and applied studies where she wrote an article The Condition of the Woman in Jane Austen's Novel 'Pride and Prejudice' in Comparison with $21^{\text {st }}$ Century Woman within the course of researching methodology and master thesis on the subject Testing Grammar and Vocabulary in Second Language Learning. In 2015 she finished masters studies at the Faculty of Philology, Romanian Language and Culture with the thesis Teaching Methods of Romanian Language with the Elements of National Culture in Eastern Serbia. In 2014 she was a scientific collaborator in writing an article One Nation, Two Languages, Many Customs published in the Austrian magazine KOSMO. Her research interests include Romanian/Vlach population in Eastern Serbia and education in Romanian language in this area.

E-mail: una.vasiljevic@yahoo.com 